\title{
5-Hydroxypicolinaldehyde Thiosemicarbazone
}

National Cancer Institute

\section{Source}

National Cancer Institute. 5-Hydroxypicolinaldehyde Thiosemicarbazone. NCI Thesaurus. Code C38468.

A thiosemicarbazone antimetabolite. A derivative of 5-hydroxypicolinaldehyde, 5-HP inhibits DNA polymerase, resulting in the inhibition of DNA replication and cell death. ( $\mathrm{NCl04)}$ 